\title{
Optimal Cost Valuation for Renewable Power Plants Using PSO in Rural Area
}

\author{
Yusra Sabri ${ }^{1}$, Hermaga Santos Zein ${ }^{2}$, and Erwin Yusuf ${ }^{1}$ \\ ${ }^{1}$ School of Electronic and Information Engineering, Institute of Technology Bandung, \\ Jalan Ganesha No. 10, Bandung 40132, Indonesia \\ ${ }^{2}$ Energy Conversion Engineering Departement, Politeknik Negeri Bandung, Indonesia \\ yusra@power.ee.itb.ac.id
}

\begin{abstract}
Cost is the main factor to run a project. Projects of renewable hybrid power plants that typically built in rural area have limited development funds. Thus, these plants should be based on an effectiveness and efficiency in order to meet the load demands with a certain reliability index. This work explains minimum cost by optimizing the cost of the power plants, Nett Present Cost or NPC, with an Equivalent Loss Factor (ELF) index to supply typical villages needs $(200 \mathrm{~kW})$, with the source of wind, solar, micro hydro and fuel cell. The result of this optimization includes batteries are used as an energy storage, which are considered as a source in the optimization process. The simulation by PSO method is proposed to solve the optimization problems. The simulation produces the equation function between Cost of Energy, LCOE and a reliability ELF index by $y=-0.016 \ln (x)+0.0131$. The lower ELF index the higher LCOE value, according to the equation function.
\end{abstract}

Keywords: particle swarm optimization, load demand, renewable, hybrid renewable power plants, HRPP, minimum cost, simulation.

\section{Introduction}

Electricity is a vital issue now and in the future, it appears as an important indicator for the quality and welfare for the community. Consumption of electric energy is closely linked with the communities of economic growth. Not all communities have the opportunity to obtain it. Many villages do not have access to grid, like rural areas, coastal areas and small islands.

To meet electricity demand for the villages, electric power has been generated from its potential energy sources. A good choice is renewable energy sources because they are friendly on environmental side. Some renewable energy sources are influenced by seasons, weather and environmental conditions such as wind and solar. Meanwhile, load patterns depend on the consumers in the village. Therefore, hybrid power supply is important to fulfill demands.

A few papers about the hybrid power plants have been published. Generally, they used the combination of the wind solar[1], and batteries as a strorage, [2][3]. Navaeefard et al. (2010) created a combination of wind, solar, battery and fuel cell [4], the combination of wind, solar, tidal and batteries [5], Or any other combinations [6][7][8][9][10][11][12]. This paper will use a combination of wind, solar, microhydro, fuel cells, and batteries as power strorage.

In its implementation, the development of hybrid system requires no small cost. However, the development of rural areas has limited funds. Thus, to overcome these problems must be done by optimization step.

\section{Problem Formulation}

The main issue of this research is how to find minimum cost of generating renewable hybrid systems (wind, solar, micro-hydro, fuel cells, and batteries) method in order to optimize the amount of each component of the hybrid system, thus align the needs of the load with a certain degree of reliability of power supply as defined in ELF Index. This renewable generation hybrid system has a lifetime benefit for twenty years. 


\section{A. System Cost Analysis}

The objective of this work is to minimize the cost function which consists of investment costs (capital costs), cost of replacement (replacement cost), operation and maintenance costs (operation and maintenance -OM- cost). Calculation of selected cost system is using Net Present Cost (NPC) method which is selected to calculate the cost system. It is formulated by this following equation (1) [3][4][5][9]:

$$
\min N P C=\sum_{i=1}^{L} N_{i}\left(C C_{i}+R C_{i} \cdot K_{i}+M C_{i} \cdot P W A(\text { ir }, R)\right)
$$

L stands for the number of renewable energy sources which consist of wind turbines, solar cells, micro-hydro, battery, and fuel cell (electrolysis, hydrogen tanks and fuel cells). N_i represents number of generating units of each of the renewable energy sources, which will be evaluated using the optimization method. The investment cost (\$/unit) is represents by CC_i , while RC_i stands for replacement cost (\$/unit). MC_i shows the operating and maintenance costs (\$/unit-year).

In order to evaluate the economic feasibility on one plant, the analysis of comparable energy costs (levelized), should be considered for all of these components. Analysis of the energy costs, called Levelized Cost of Energy (LCOE), this LCOE is calculated by the following equation [13]:

$$
L C O E=\frac{\text { Total annualized cost }(\text { USD } / \text { year })}{\text { Annual load served }(k W h / \text { year })}(U S D / k W h)
$$

Finding the LCOE value, total value of the project NPC should be converted into series of annual cash flows known as total annualized cost. The following equation (3) is used to calculate the total annualized cost.

Total annualized cost $(\$ /$ year $)=$ Total NPC $\times \mathrm{CRF}$

CRF is the capital recovery factor as it is represented by this following formula:

$$
C R F(i r, n)=\frac{\left(i r \cdot(1+i r)^{n}\right)}{(1+i r)^{n-1}}
$$

\section{B. Equivalent Loss Factor (ELF) Index}

Equivalent Loss Factor (ELF) index provides information on the number of energy load cannot be supplied by Hybrid Renewable Power Plant (HRPP) at each time interval. The advantage of this index is able to determine the generation capacity with or without taking into account the possibility of the unexpected. ELF index can be expressed by equation Error! Reference source not found. follows [4][5][10][14].

$$
\mathrm{ELF}=\frac{1}{\mathrm{~T}} \sum_{\mathrm{t}=1}^{\mathrm{T}} \frac{\mathrm{Q}_{\mathrm{t}}}{\mathrm{D}_{\mathrm{t}}}
$$

Where, $Q_{t}$ is a total loss of load each time interval and $D_{t}$ is the total load demand each time interval. Meanwhile, $\mathrm{T}$ is the total number of time interval (1 hour). The data used in this study is one year, which means 8760 hours.

In an ideal system, where the load demand will always be supplied, the ELF value will equal to 0 . Therefore, when the value of the ELF $>0$, that means sometimes the load demand cannot be met by HRPP. Some utility companies in developing countries set ELF $<0.0001$ for mikrogrid applications that are not connected to the grid. While in some underdeveloped countries usually set ELF <0.01 [7][14][15]. 


\section{Hybrid Renewable Power Plant Model}

In this work, renewable hybrid system resources are contained of sunlight, wind and river flow. Energy storage system which consisted of battery and fuel cells are important to maintaining the balance supply and demand of the energy. Figure 1 shows the renewable hybrid power system consisting of solar cells, wind turbines, micro hydro, fuel cells and batteries.

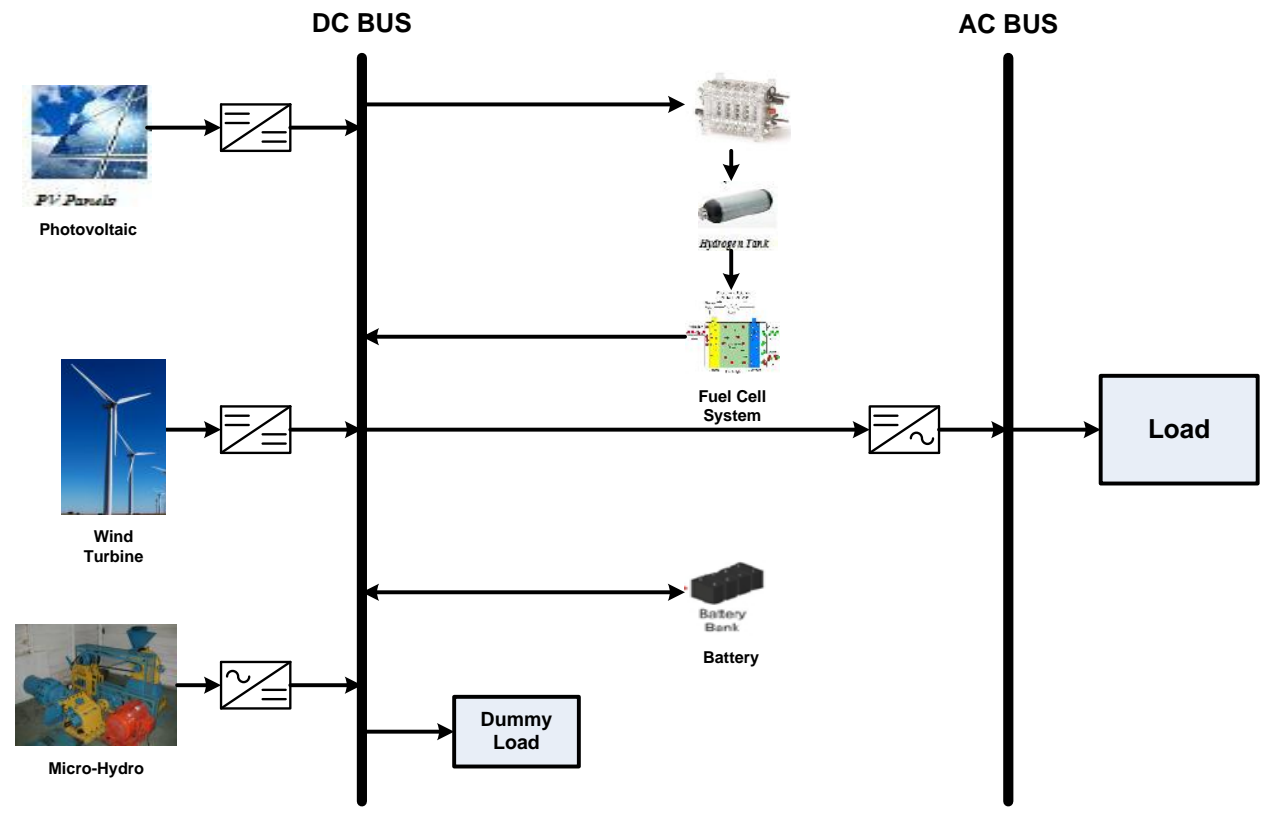

Figure 1. Hybrid Renewable Power Plant consist of Photovoltaic, Wind Turbine, Microhydro, Fuel Cell and Battery

\section{A. Wind Turbine}

The determination of an appropriate model of wind turbines is important, since the characteristics of the power output from wind turbine can be different depending on the type also power value (rated). In this work, a BWC Excel-R/48 wind turbines type is used, which the power output characteristic shown in figure 2 .

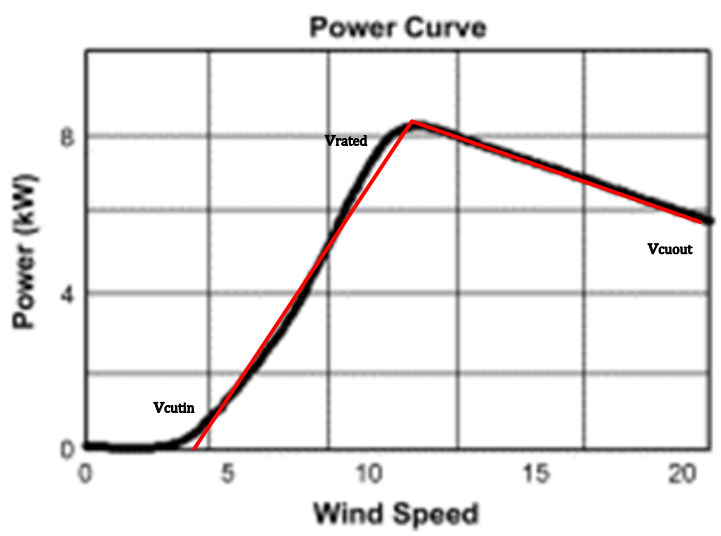

Figure 2. Excel-R/48 power output characteristic [11]

Based on figure 2, the characteristics of the wind turbine output power $\left(\mathrm{P}_{\mathrm{wg}, \mathrm{t}}\right)$ in term of wind speed is shown in equation (6) follows [4][5][9]: 


$$
\mathrm{P}_{\mathrm{wg}, \mathrm{t}}=\left\{\begin{array}{cc}
0 & \mathrm{v}_{\mathrm{t}}<\mathrm{v}_{\text {cutin }}, \mathrm{v}_{\mathrm{t}}>\mathrm{v}_{\text {cutout }} \\
\mathrm{P}_{\max }\left(\frac{\mathrm{v}_{\mathrm{t}}-\mathrm{v}_{\text {cutin }}}{\mathrm{v}_{\text {rated }}-\mathrm{v}_{\text {cutin }}}\right) & \mathrm{v}_{\text {cutin }} \leq \mathrm{v}_{\mathrm{t}} \leq \mathrm{v}_{\text {rated }} \\
\mathrm{p}_{\text {max }}+\left(\frac{\mathrm{p}_{\text {furl }}-\mathrm{p}_{\max }}{\mathrm{v}_{\text {cutout }}-\mathrm{v}_{\text {rated }}}\right) \cdot\left(\mathrm{v}_{\mathrm{t}}-\mathrm{v}_{\text {rated }}\right) & \mathrm{v}_{\text {rated }}<\mathrm{v}_{\mathrm{t}} \leq \mathrm{v}_{\text {cutout }}
\end{array}\right.
$$

Where, $v_{t}$ is wind speed at a single time interval, $v_{\text {cutin }}$ is value of the cut-in wind speed, $v_{\text {cutout }}$ is value of the cut outwind speed and $v_{\text {rated }}$ is value of wind rate speed $(\mathrm{m} / \mathrm{s}) \cdot \mathrm{p}_{\max }$ is the maximum output power and $\mathrm{p}_{\text {furl }}$ is the output power at the cut-out speed $(\mathrm{kW})$ calculated after passing through the inverter.

\section{B. Photovoltaic}

The output power of the solar cell system is strongly influenced by the level of solar radiation and ambient temperature which affects the solar cell. There are several methods that can be used to calculate the output power from the solar cell system. The easiest method is using comparison between output power (darimana) which generated by the output power of the factory. Test results in STC (Standard Test Conditions irradiance 1000W/m2, AM1.5 spectrum with $25^{\circ} \mathrm{C}$ of solar cell temperature), as shown in equation (7) [2][5][9]. This equation can used the assumption that the surface temperature of the solar cells is constant in $25^{\circ} \mathrm{C}$ during the day throughout the year.

$$
\mathrm{P}_{\mathrm{pv}, \mathrm{t}}=\frac{\mathrm{G}_{\mathrm{t}}}{\mathrm{G}_{\mathrm{stc}}} \cdot \mathrm{P}_{\mathrm{PV}, \text { rated }} \cdot \eta_{\mathrm{PV}, \mathrm{conv}}
$$

Where $G_{t}$ is the solar radiation on photovoltaic array every time of interval $(\mathrm{W} / \mathrm{m} 2), G_{\text {stc }}$ is the standard radiation test on the photovoltaic equipment equal to $1000(\mathrm{~W} / \mathrm{m} 2)$. $\mathrm{P}_{\mathrm{PV} \text {,rated }}$ is rate power of each photovoltaic array $(\mathrm{kW})$ and $\eta_{\mathrm{PV} \text {,conv }}$ is solar cells efficiency due to temperature rise and DC/DC converter for each of photovoltaic array.

\section{Micro-hydro Power plant (MHP)}

In this work, MHP is designed to supply the base load. Thus, the expected power output from the MHP will always constant throughout the year. Shortly, the constant of water flows and head are required. As shown in this following equation (8).

$$
\mathrm{P}_{\mathrm{mh}}=\rho \cdot \mathrm{g} \cdot \mathrm{H} \cdot \mathrm{Q} \cdot \eta
$$

The power generated by the MHP $\left(\mathrm{P}_{\mathrm{mh}}\right)$ is depends on the discharge Q $(\mathrm{m} 3 / \mathrm{s})$ and the head $\mathrm{H}(\mathrm{m})$. In order to get the value of constant discharge and head, the micro-hydro power plants (MHP) are using a run-of-river scheme.

To get the value of a constant discharge, flow duration curve can be used. From these curves will get mainstay discharge, which is a minimum discharge at the highest possibilities in river flows. Due to the value of the constant discharge and head, then the MHP output power will be considered constant in every time interval.

\section{Battery Charging and Discharging State}

Battery is a traditional electrical energy storage device that has a high efficiency. Similar a water tank, battery will accommodate the producing of electrical energy using the renewable generator of its suit capacity. Further, battery will supply the load when needed and drain the energy to a minimum (depth of discharge) capacity. The difference between the power generation and load demand are depended on the condition of charging. The principle of charging and discharging depends on the state $\left(\mathrm{P}_{\text {ren, } \mathrm{t}}\right)$ and the load power demand at time $\mathrm{t}\left(\mathrm{P}_{\text {load, }}\right)$. 
Basic principle of battery operation explained as follows. The power from battery is needed when the renewable hybrid generation $\left(\mathrm{P}_{\text {ren,t }}\right)$ is not able to provide power according to the load demand $\left(\mathrm{P}_{\text {load, } t} / \eta_{\text {inv }},\right)$. When the renewable generation produced higher power than the load demand, remained generating power from renewable generation will be stored to the battery. Every hour, battery charge status is associated with the state before it charging. Production of energy absorbed by the battery during the time $(t-1)$ to $(t)$ are described on this following equation (9) [12].

$$
\mathrm{C}_{\mathrm{bat}, \mathrm{t}}=\mathrm{C}_{\mathrm{bat},(\mathrm{t}-1)} \cdot(1-\sigma)+\mathrm{P}_{\mathrm{batc}, \mathrm{t}}
$$

$\mathrm{C}_{\mathrm{bat}, \mathrm{t}}$ and $\mathrm{C}_{\mathrm{bat},(\mathrm{t}-1)}$, are the number of the energy which available inside of the battery, When time ( $\mathrm{t}$ ) and the previous time (t-1), is the personal used value of battery per hour, some studies assumed 0.002 [12]. While $\mathrm{P}_{\mathrm{batc}, \mathrm{t}}$ is power generated by the renewable energy sources to charge batteries per time interval, conditions can be described mathematically by the following equation (10) [2].

$$
\mathrm{P}_{\text {batc,t }}=\left(\mathrm{P}_{\text {ren,t }}-\mathrm{P}_{\text {load }, \mathrm{t}} / \eta_{\text {inv }}\right) \eta_{\text {charge }}
$$

$P_{\text {load,t }}$ stands for demand $(\mathrm{kW}), \eta_{\text {inv }}$ and $\eta_{\text {charge }}$ each are the efficiency inverter DC / AC (90\%) and charging efficiency (90\%)[4].

When the renewable power plants are not possible to fulfill the load demand, load demand will get power supply from the battery and fuel cell sequentially.

Mathematical equation for battery consumption is written in this following sequence (11).

$$
\mathrm{P}_{\text {batd, } \mathrm{t}}=\left(\mathrm{P}_{\text {load, } \mathrm{t}} / \eta_{\text {inv }}-\mathrm{P}_{\text {ren, } \mathrm{t}}\right) / \eta_{\text {discharge }}
$$

When battery is going to discharge, it will certainly reduce capacity. Reduced capacity of the battery at the time of discharge during the time $(t-1)$ to $(t)$ is described in this following equation (12) [2].

$$
\mathrm{C}_{\mathrm{bat}, \mathrm{t}}=\mathrm{C}_{\mathrm{bat},(\mathrm{t}-1)} \cdot(1-\sigma)-\mathrm{P}_{\mathrm{batd}, \mathrm{t}}
$$

\section{E. Fuel Cell Charging and Discharging State}

E.1. Electrolyser Mathematical Formulation

When the battery fully charged to capacity, the excess power will be used for the process of electrolysis to produce hydrogen. Power results from the electrolysis electrolizer, $\mathrm{P}_{\mathrm{el}, \mathrm{t}}$ can be calculated using following equation Error! Reference source not found. [4][9].

$$
\mathrm{P}_{\mathrm{el}, \mathrm{t}}=\left(\mathrm{P}_{\text {ren,t }}-\mathrm{P}_{\text {load,t }} / \eta_{\text {inv }}\right) \cdot \eta_{\mathrm{el}}
$$

Since, $P_{\mathrm{el}, \mathrm{t}}$ electrolyzer sent from renewable generation, and $\eta_{\mathrm{el}}$ is the efficiency of elektrolyzer.

\section{E.2. Hydrogen Tank Mathematical Formulation}

Energy supplied to hydrogen tank for each time of interval can be calculated by the following equation Error! Reference source not found.:

$$
\mathrm{C}_{\text {tank,t }}=\mathrm{C}_{\text {tank,(t-1) }}+\mathrm{P}_{\mathrm{el}, \mathrm{t}} \cdot \eta_{\text {storage }}
$$


$\mathrm{C}_{\mathrm{tank}, \mathrm{t}}$ and $\mathrm{C}_{\operatorname{tank},(\mathrm{t}-1)}$, are the availability of energy in the hydrogen tank when the time $(\mathrm{t})$, the previous time $(t-1)$, and $\eta_{\text {storage }}$ stands for the efficiency of the storage system that assumed $95 \%$ [4][9].

Calculate the output energy from the hydrogen tank to the fuel cell used the following equation Error! Reference source not found.:

$$
\mathrm{C}_{\mathrm{tank}, \mathrm{t}}=\mathrm{C}_{\mathrm{tank},(\mathrm{t}-1)}-\mathrm{P}_{\mathrm{fc}, \mathrm{t}}
$$

\section{E.3. Fuel cell Mathematical Formulation}

This work used Proton Exchange Membrane (PEM) fuel cell type. PEM has a reliable performance in non-continuous operating conditions [4][8]. The output power from the fuel cell is directly proportional to the input power of hydrogen, $\eta_{\mathrm{fc}}$ efficiency can be assumed as constant, meanwhile, output power of the fuel cell at time interval $\mathrm{P}_{\mathrm{fc}, \mathrm{t}}$ can be calculated using the equation Error! Reference source not found.[4].

$$
\mathrm{P}_{\mathrm{fc}, \mathrm{t}}=\left(\mathrm{P}_{\text {load, } \mathrm{t}} / \eta_{\text {inv }}-\mathrm{P}_{\text {ren, } \mathrm{t}}\right) / \eta_{\mathrm{fc}}
$$

\section{Optimization of Hybrid Renewable Power Plant by Particle Swarm Optimization}

A. Particle Swarm Optimization Theory

Optimization technique is an action that attempts to obtain the best results in certain circumstances. Optimization can be defined as the process of finding the conditions that give the maximum or minimum value of a function. One of the modern optimization methods which are usually used is the Particle Swarm Optimization. The Particle Swarm Optimization (PSO) [16] method is a multi-agent parallel search technique which keeps a group of particles and each particle as a representation potential solution in a population. The main job of branch in PSO called particles, and a group or a population of particles called swarm. Each particle consists of a vector as a potential solution in the optimization problem that has its own position $\mathrm{X}$ and velocity $\mathrm{V}$. Each particle also keeps track of the coordinates in the problem space and updates its position based on its own best exploration associated with the best solution (fitness). The following example is an updated velocity equation Error! Reference source not found. and position Error! Reference source not found. in the PSO.

$$
\begin{aligned}
& V_{j}(k+1)=\omega V_{j}(k)+c_{1} r_{1}\left[P_{\text {best }, j}-X_{j}(k)\right]+c_{2} r_{2}\left[G_{\text {best }}-X_{j}(k)\right] ; \\
& j=1,2, \ldots, N \\
& X_{j}(k+1)=X_{j}(k)+V_{j}(k+1) ; j=1,2, \ldots, N
\end{aligned}
$$

There is a weighting factor $(\omega)$ to manipulate the impact of history speed to the current speed. Usually the value of $\omega$ is made, so the increasing of iteration are passed, the smaller of particle velocity. $r_{1} r 1$ and $r 2 r_{2}$ are random numbers uniformly distributed in the interval 0 to 1. $c_{1} r_{1}$ and $c_{2} r_{2}$ are learning rates for individual ability (cognitive) and social influences (group). $c_{1}$ and $c_{2}$ indicates the weight of memory (position) of a particle to memory (position) of the group (swarm). Value of $c_{1} r_{1}$ and $c_{2} r_{2}$ usually on a same value, so the multiplication $\mathrm{c}_{1} \mathrm{r}_{1}$ andc $\mathrm{r}_{2}$ ensure that the particles will approached the target about half the difference. $\mathrm{P}_{\mathrm{best}, \mathrm{j}}(\mathrm{k})$ is the best position particle $\mathrm{j}$ ever experienced until iteration $\mathrm{k}$ and $\mathrm{G}_{\mathrm{best}}(\mathrm{k})$ is the best position discovered by the particles in the entire swarm.

\section{B. Implementation of Particle Swarm Optimization to Optimize Size of Hybrid Renewable Power Plant}

The PSO mechanism to optimize HRPP can be seen in figure 3 and described in accordance with the following steps: 


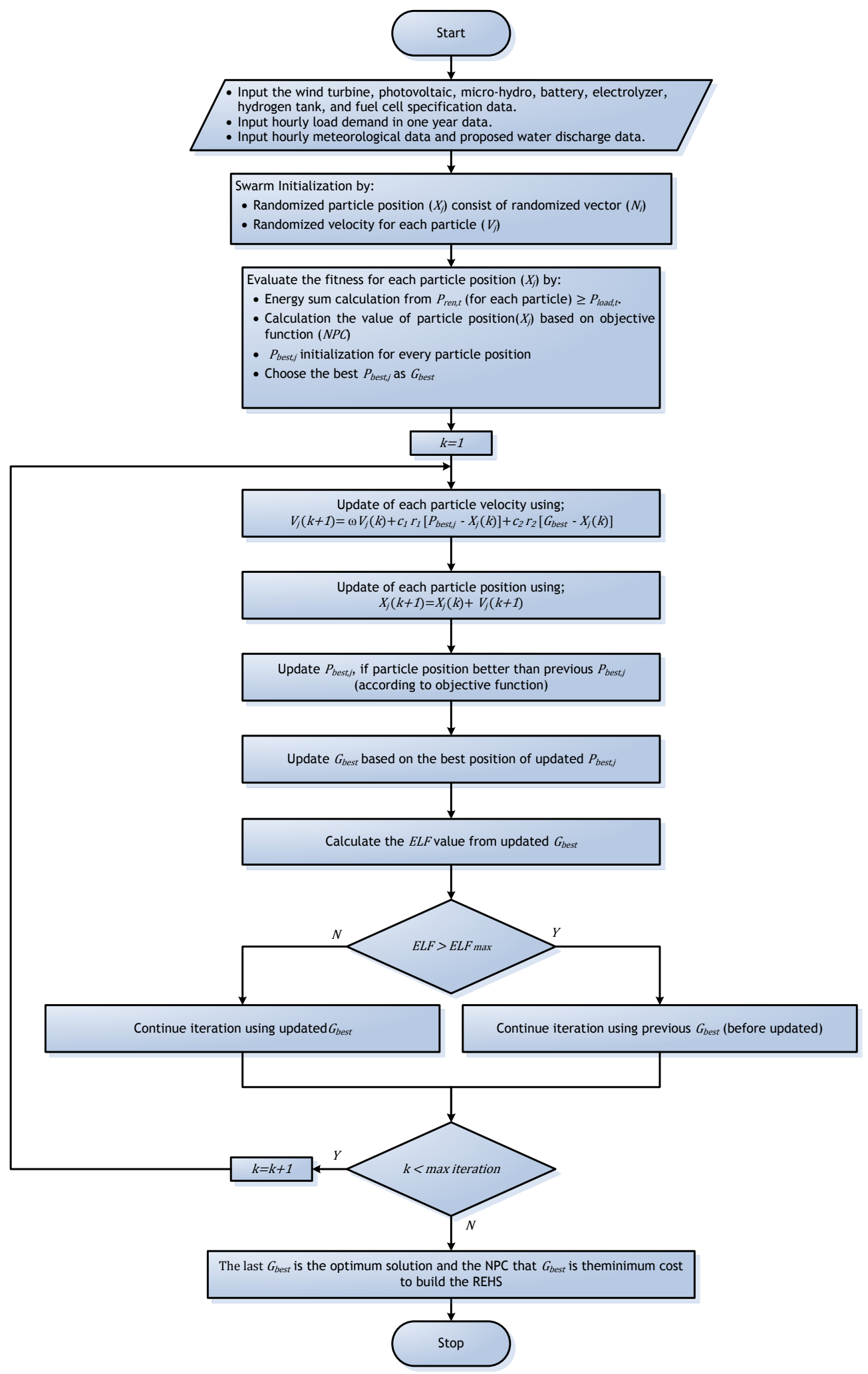

Figure 3. PSO algorithm application HRPP simulation 
Yusra Sabri, et al.

C. Equivalent Loss Factor Calculation Simulation

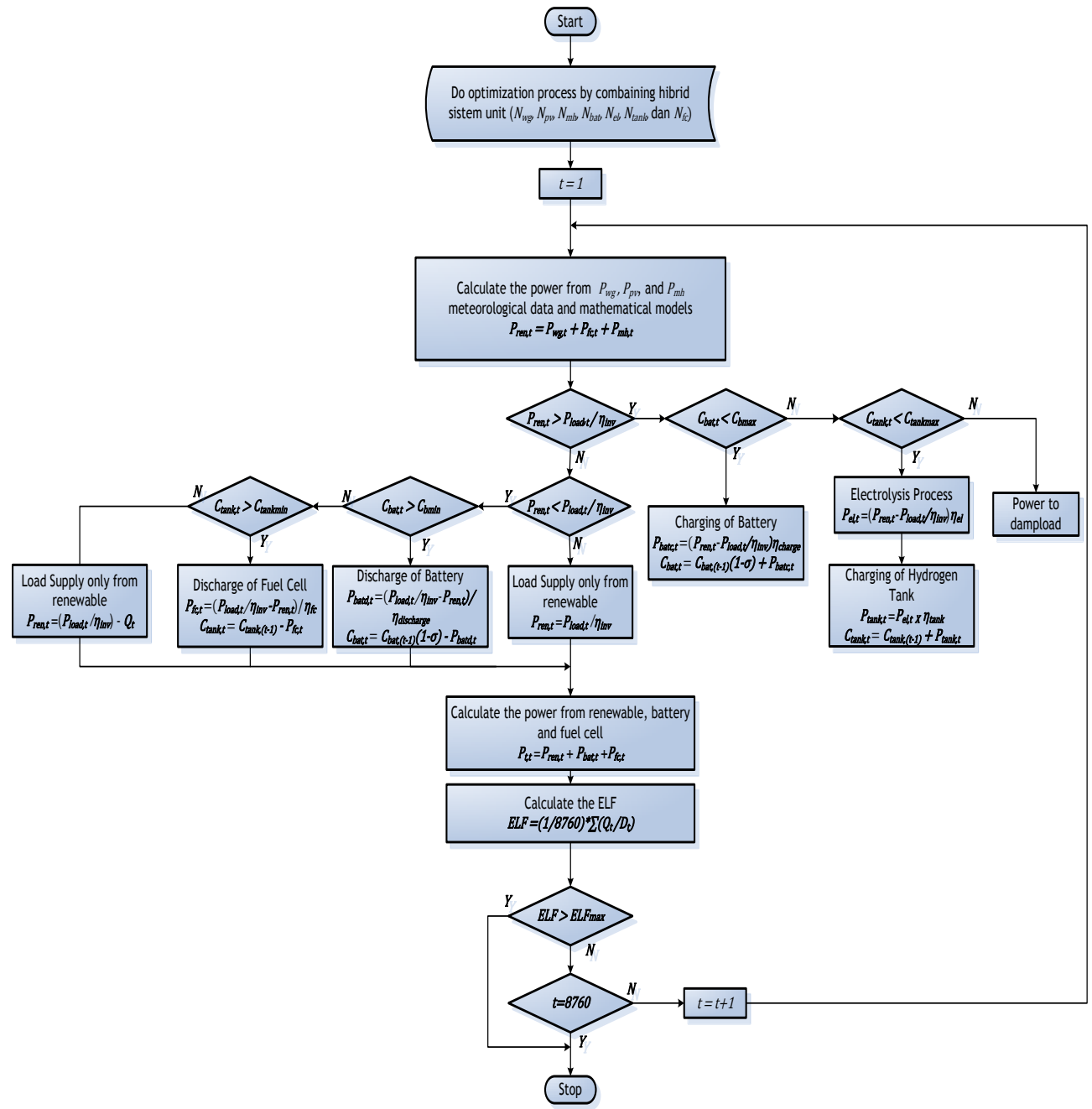

Figure 4. Hybrid renewable power plant operation system

In an electric power system, a generation system made to meet the needs of the electricity customers. Electricity producers will meet the load demands in accordance with certain reliability index. In this study, ELF is determined as power supply reliability index that compares the difference in energy supply to load requirement in one year. Calculation simulation to obtain ELF is consists of three (3) stages:

Stage-1, calculate the renewable power generation based on the number of each generating unit derived from PSO simulation results, equation model of each component of the power plant as well per hour of meteorological data for one year. This was done to determine the capacity of the power that can be generated by renewable generation within an hour during the year.

Stage-2, hourly power generated by renewable generation will be simulated according the following three circumstances or states:

- $1^{\text {st }}$ state

$$
P_{\text {ren, },}=\frac{P_{\text {load }, t}}{\eta_{\text {inv }}}
$$


First stage (1), assume all the power generated by renewable generators (wind turbines, solar cells, micro-hydro) in accordance with the load power demand. Means the power is routed through DC / AC inverter to the load. This causes the capacity of the hydrogen tank and battery not to change.

- $2^{\text {nd }}$ state

$$
P_{\text {ren }, t}>\frac{P_{\text {load }, t}}{\eta_{\text {inv }}}
$$

Second state (2), the power generated by renewable generation is larger than the load demand. In this situation, most of the power generated by renewable power is consumed by the load. If the capacity of the battery and hydrogen tank has not reached $100 \%$, the excess power will be stored to the battery and hydrogen tank. If the capacity of the battery and hydrogen tank is $100 \%$ or $100 \%$ after charging time, the surplus power will be consumed by the dummy load.

- $3^{\text {rd }}$ state

$$
\mathrm{P}_{\text {ren,t }}<\frac{\mathrm{P}_{\text {load,t }}}{\eta_{\text {inv }}}
$$

In the third state (3), the power generated by renewable power generation is less than the load demand. Thus, all of the power generated by renewable power will be supplied to the load. The drawback will be supplied by the battery during battery capacity greater than or equal to the depth of discharge and the fuel cell as long as there is supply of hydrogen in the tank. If the battery and the fuel cell can no shortage of power supply, there will be load shedding or load barrier. In the above circumstances, the constraints have to be considered and all the system equations must be considered

Stage-3, calculate the supply reliability index (ELF) of Hybrid Renewable Power Plant based on the number of components units were obtained from the simulation results of PSO. PSO simulation is repeated to get the best value from the PSO population into an optimal solution of the problem. With this simulation, the PSO will try to find the optimal size of the system.

\section{Simulation and Analysis}

A. Data and Hybrid System Component Specification

\section{A.1. Load Data}

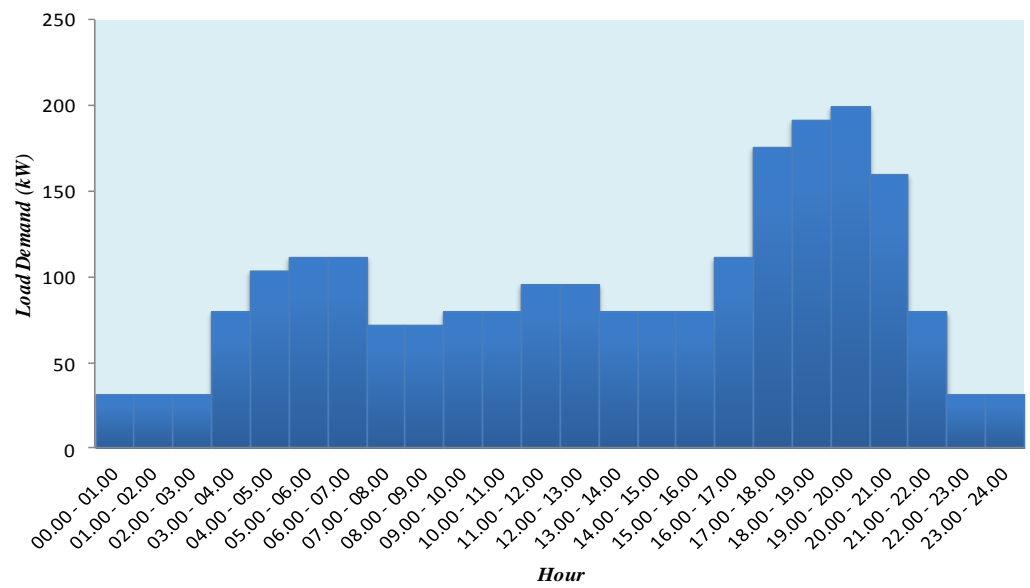

Figure 5. Hourly load profile curve in a day 
HRPP is simulated to meet the load demand in a village in a rural area that has not electrification previously with an estimated peak load of around $200 \mathrm{~kW}$ with $811.760 \mathrm{kWh}$ energy consumption per year. Load curve of the year is the sum of the daily load profile assuming daily rural community activities is the same for all year.

\section{A.2. Wind Speed and Wind Turbine Specification Data}

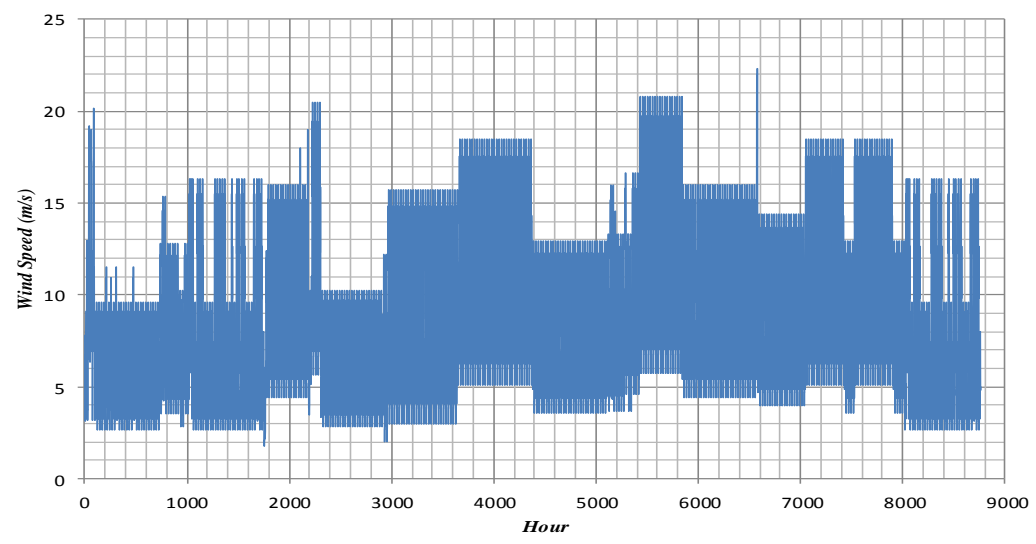

Figure 6. Hourly wind Speed in one year

This work is using the BWC Excel-R / 48 from Bergey Wind Power's consider of the wind resource potential with maximum speed of $22.32(\mathrm{~m} / \mathrm{s})$ and $1.76(\mathrm{~m} / \mathrm{s})$ as the minimum number with an average of about $8.66(\mathrm{~m} / \mathrm{s}$ ) (figure 6). This turbine rated power capacity is $7.5 \mathrm{~kW}$ with 48 volts (dc) as output voltage. The full specifications and costs of the wind turbine are shown in table 1 [4][5][9].

Table 1. Wind Turbine Specification

\begin{tabular}{|l|c|c|}
\hline Cut-in Speed & $\mathrm{v}_{\text {cutin }}$ & $3(\mathrm{~m} / \mathrm{s})$ \\
\hline Cut-out Speed & $\mathrm{v}_{\text {cutout }}$ & $25(\mathrm{~m} / \mathrm{s})$ \\
\hline Rated Speed & $\mathrm{v}_{\text {rated }}$ & $15(\mathrm{~m} / \mathrm{s})$ \\
\hline Maximum Power Output & $\mathrm{p}_{\max }$ & $8,1(\mathrm{~kW})$ \\
\hline Cut-out Power Output & $\mathrm{p}_{\text {furl }}$ & $5,8(\mathrm{~kW})$ \\
\hline Capital Cost & CC & $16.400(\$ /$ Unit $)$ \\
\hline Replacement Cost & $\mathrm{RC}$ & $13.000(\$ /$ Unit $)$ \\
\hline Operation and Maintenance Cost & MC & $400(\$ /$ Unit-year $)$ \\
\hline
\end{tabular}

\section{A.3. Solar Radiation and Photovoltaic Specification Data}

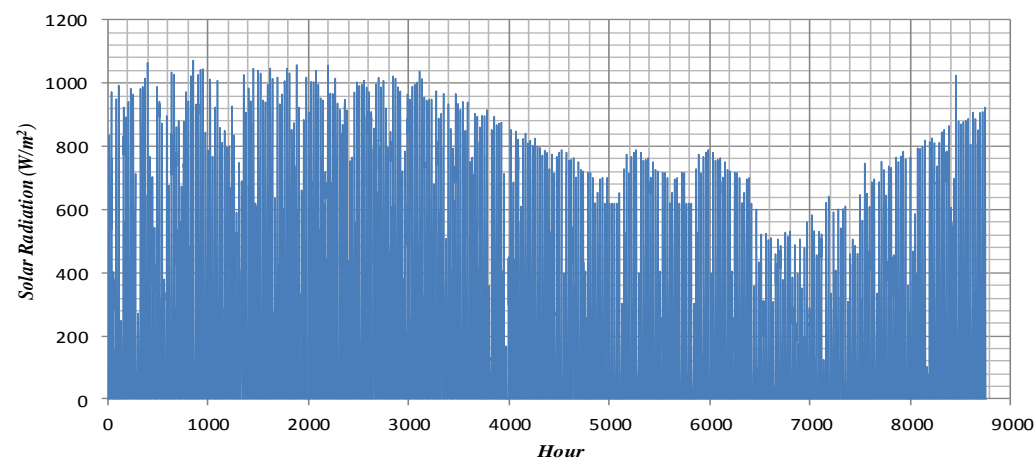

Figure 7. Hourly solar radiation in one year 
Solar radiation data derived from regions close to the equator, the availability of solar energy always be available throughout the year (figure7). This work using Canadian Solar CS6P-240P as the Solar cell modules. The specific data of Canadian Solar CS6P-240P can be seen in table 2 [13].

Table 2. Photovoltaic Specification

\begin{tabular}{|l|c|c|}
\hline Photovoltaic Rated Power & $\mathrm{P}_{\mathrm{PV}, \text { rated }}$ & $0,96(\mathrm{~kW})$ \\
\hline Efficiency & $\eta_{\mathrm{PV}, \text { conv }}$ & 0,9 \\
\hline Lifetime & & 20 (year) \\
\hline Capital Cost & $\mathrm{CC}$ & $3.000(\$ /$ Unit $)$ \\
\hline Replacement Cost & $\mathrm{RC}$ & $1.300(\$ /$ Unit $)$ \\
\hline Operation and Maintenance Cost & $\mathrm{MC}$ & $20(\$ /$ Unit-year $)$ \\
\hline
\end{tabular}

\section{A.4. Micro-hydro Specification Data}

Micro-hydro power plant that will be used in this study has specification as follow in table 3.

Table 3 Micro-hydro Specification

\begin{tabular}{|l|c|c|}
\hline Micro-hydro Rated Power & $\mathrm{P}_{\mathrm{MH}, \text { rated }}$ & $10,8(\mathrm{~kW})$ \\
\hline Rated Discharge & $\mathrm{q}_{\text {rated }}$ & $0,3(\mathrm{~m} 3 / \mathrm{s})$ \\
\hline Head & $\mathrm{H}$ & $6(\mathrm{~m})$ \\
\hline Lifetime & & $20($ year $)$ \\
\hline Capital Cost & $\mathrm{CC}$ & $25.000(\$ /$ Unit $)$ \\
\hline Replacement Cost & $\mathrm{RC}$ & $1.300(\$ /$ Unit $)$ \\
\hline Operation and Maintenance Cost & $\mathrm{MC}$ & $750(\$ /$ Unit-year $)$ \\
\hline
\end{tabular}

\section{A.5. Storage Component Specification Data}

This work will use two kind of storage systems, Surrette-6CS25P with a nominal voltage of 6 volts and 6.94 energy rate $(\mathrm{kWh})$ battery and fuel cell systems, assumed the battery lifetime is 10 years, with the depth of discharge about $80 \%$. The cost of batteries and other parameters are shown in table 4[5].

Table 4. Battery Specification

\begin{tabular}{|l|c|c|}
\hline Battery Capacity & & $6,94(\mathrm{kWh})$ \\
\hline Charging Efficiency & $\eta_{\text {charge }}$ & 0,8 \\
\hline Discharging Efficiency & $\eta_{\text {discharge }}$ & 0,8 \\
\hline Lifetime & & 10 (year) \\
\hline DOD & & 0,8 \\
\hline Capital Cost & CC & $1.250(\$ /$ Unit $)$ \\
\hline Replacement Cost & RC & $1.000(\$ /$ Unit $)$ \\
\hline Operation and Maintenance Cost & MC & $20(\$ /$ Unit-year $)$ \\
\hline
\end{tabular}

Fuel cell systems consist of Electrolyser, Hydrogen Tank and Fuel Cell. Specifications of fuel cell system are shown in the following

table 5, Error! Reference source not found.,

table 7.

Table 5. Electrolyser Specification [20]

\begin{tabular}{|l|c|c|}
\hline Electrolyser Capacity & & $1 \mathrm{kWh}$ \\
\hline Electrolyser Efficiency & $\eta_{\mathrm{el}}$ & 0,9 \\
\hline Lifetime & & 20 (year) \\
\hline Capital Cost & $\mathrm{CC}$ & $3.000(\$ /$ Unit $)$ \\
\hline
\end{tabular}




\begin{tabular}{|l|c|c|}
\hline Replacement Cost & RC & $2.500(\$ /$ Unit $)$ \\
\hline Operation and Maintenance Cost & MC & $40(\$ /$ Unit-year $)$ \\
\hline
\end{tabular}

Table 6. Hydrogen Tank Specification [21]

\begin{tabular}{|l|c|c|}
\hline Hydrogen Tank Capacity & $\mathrm{m}$ & $2 \mathrm{~kg}$ \\
\hline Hydrogen Tank Efficiency & $\eta_{\text {storage }}$ & 0.8 \\
\hline Lifetime & & $20($ year $)$ \\
\hline Capital Cost & $\mathrm{CC}$ & $3.360(\$ /$ Unit $)$ \\
\hline Replacement Cost & $\mathrm{RC}$ & $3.200(\$ /$ Unit $)$ \\
\hline Operation and Maintenance Cost & $\mathrm{MC}$ & $15($ \$nit-year $)$ \\
\hline
\end{tabular}

Table 7. Fuel Cell Specification [20]

\begin{tabular}{|l|c|c|}
\hline Fuel Cell Capacity & & $0,5 \mathrm{kWh}$ \\
\hline Fuel Cell Efficiency & $\eta_{\mathrm{fc}}$ & 0,7 \\
\hline Lifetime & & $20($ year $)$ \\
\hline Capital Cost & $\mathrm{CC}$ & $3.000(\$ /$ Unit $)$ \\
\hline Replacement Cost & $\mathrm{RC}$ & $2.500(\$ /$ Unit $)$ \\
\hline Operation and Maintenance Cost & $\mathrm{MC}$ & $175(\$ /$ Unit-year $)$ \\
\hline
\end{tabular}

\section{Simulation Result and Analysis}

PSO simulation program using the code of matlab $m$-files have been developed to determine the optimal configuration of Hybrid Renewable Power Plants. Simulations run on computers with a processor speed of $1.6 \mathrm{GHz}$ and $2 \mathrm{~GB}$ of RAM. This configuration optimization based on load profile data by one hour in a year based on the daily load profile in figure 5 is considered to be constant during the year.PSO simulation program is run based on the parameters listed in table 8 .

Table 8. PSO Simulation Parameter

\begin{tabular}{|c|c|c|c|c|}
\hline Population & $\mathrm{c}_{1}$ & $\mathrm{c}_{2}$ & $\omega_{\max }$ & $\omega_{\min }$ \\
\hline 20 & 1.2 & 1.2 & 0.9 & 0.3 \\
\hline
\end{tabular}

The simulation was done several times using different initial values by maximum iteration is 100 iterations. Simulation was conducted for different ELF $_{\text {mak }}$ between 0.1, 0.01 and 0.0001. Suppose that for $\mathrm{ELF}_{\mathrm{mak}}=0.01$, the convergence is obtained in $65^{\text {th }}$ iterations from 100 iterations in 10 minutes, as shown in figure $\mathbf{8}$.

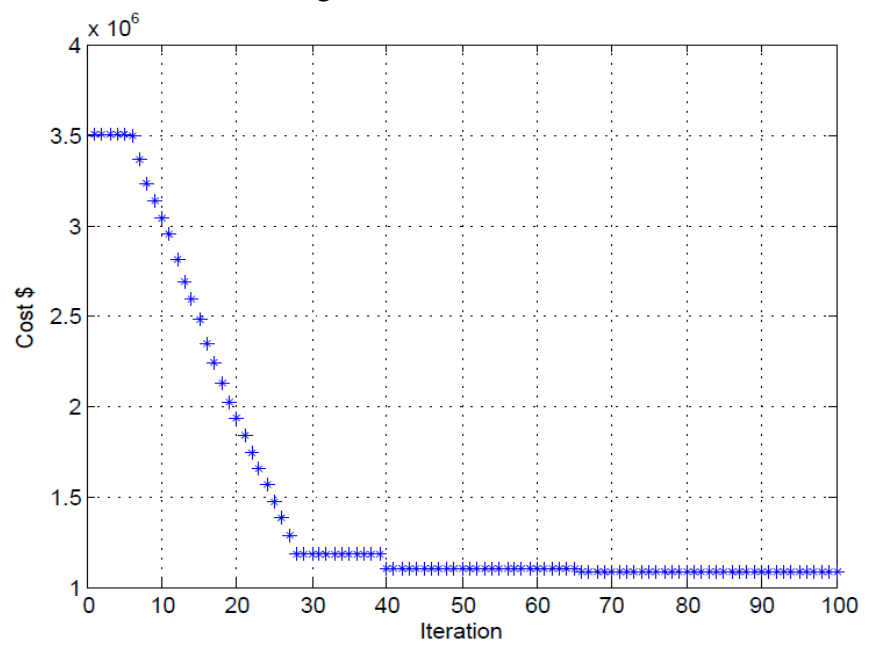

Figure 8. Convergence of the PSO optimization for $\mathrm{ELF}_{\mathrm{mak}}=0,01$ 
After several run was obtained convergence simulation result with the low NPC value as shown in table 9.

Table 9. Simulation result of optimized parameter and cost of hibrid system

\begin{tabular}{|c|c|c|c|c|c|c|c|c|c|}
\hline $\mathbf{N o}$ & $\mathbf{E L F}$ & $\mathbf{N}_{\mathbf{w g}}$ & $\mathbf{N}_{\mathbf{p v}}$ & $\mathbf{N}_{\mathbf{m h}}$ & $\mathbf{N}_{\mathbf{b a t}}$ & $\mathbf{N}_{\mathbf{e l}}$ & $\mathbf{N}_{\text {tank }}$ & $\mathbf{N}_{\mathbf{f c}}$ & $\mathbf{N P C} \mathbf{( \$ )}$ \\
\hline 1 & 0.0001 & 38 & 66 & 3 & 134 & 0 & 0 & 0 & $1,510,100$ \\
\hline 2 & 0.001 & 34 & 45 & 3 & 108 & 0 & 0 & 0 & $1,235,400$ \\
\hline 3 & 0.01 & 34 & 41 & 3 & 51 & 0 & 0 & 0 & $1,087,700$ \\
\hline 4 & 0.02 & 28 & 39 & 3 & 52 & 0 & 0 & 0 & 972,010 \\
\hline 5 & 0.03 & 26 & 34 & 3 & 48 & 0 & 0 & 0 & 893,120 \\
\hline 6 & 0.04 & 27 & 24 & 3 & 46 & 0 & 0 & 0 & 833,980 \\
\hline 7 & 0.05 & 22 & 26 & 3 & 53 & 0 & 0 & 0 & 776,880 \\
\hline 8 & 0.06 & 22 & 25 & 3 & 41 & 0 & 0 & 0 & 744,650 \\
\hline 9 & 0.07 & 19 & 25 & 3 & 51 & 0 & 0 & 0 & 713,820 \\
\hline 10 & 0.08 & 18 & 22 & 3 & 52 & 0 & 0 & 0 & 677,020 \\
\hline 11 & 0.09 & 18 & 14 & 3 & 63 & 0 & 0 & 0 & 642,190 \\
\hline 12 & 0.1 & 18 & 21 & 3 & 34 & 0 & 0 & 0 & 632,280 \\
\hline
\end{tabular}

Simulation results shown the value electrolizer, hydrogen tank, and fuel cell components is zero, which indicates if today, compared to the battery, fuel cell technology is still really expensive for energy storage applications in HRPP. Smaller the ELF value, greater the cost (NPC) are shown on the tabel above. Since the number of components to serve load demand increases, especially inside of the energy storage system, the equation (2) and (3) are used to calculate the LCOE

From the result of the conducted simulation, different configurations of the proposed were found. The best configuration of a hybrid system based on renewable energy equipment specification data, load and meteorological obtained:

Table 10. Kofiguration Optimization of HRPP

\begin{tabular}{|c|c|c|c|c|c|c|c|}
\hline $\mathbf{N o}$ & $\mathbf{E L F}$ & $\mathbf{N}_{\mathbf{w g}}$ & $\mathbf{N}_{\mathbf{p v}}$ & $\mathbf{N}_{\mathbf{m h}}$ & $\mathbf{N}_{\text {bat }}$ & $\mathbf{N P C} \mathbf{( \$ )}$ & $\mathbf{L C O E} \mathbf{( \$ / \mathbf { k W h } )}$ \\
\hline 1 & 0.0001 & 38 & 66 & 3 & 134 & $1,510,100$ & 0.12 \\
\hline 2 & 0.001 & 34 & 45 & 3 & 108 & $1,235,400$ & 0.10 \\
\hline 3 & 0.01 & 34 & 41 & 3 & 51 & $1,087,700$ & 0.09 \\
\hline 4 & 0.02 & 28 & 39 & 3 & 52 & 972,010 & 0.08 \\
\hline 5 & 0.03 & 26 & 34 & 3 & 48 & 893,120 & 0.07 \\
\hline 6 & 0.04 & 27 & 24 & 3 & 46 & 833,980 & 0.07 \\
\hline 7 & 0.05 & 22 & 26 & 3 & 53 & 776,880 & 0.06 \\
\hline 8 & 0.06 & 22 & 25 & 3 & 41 & 744,650 & 0.06 \\
\hline 9 & 0.07 & 19 & 25 & 3 & 51 & 713,820 & 0.06 \\
\hline 10 & 0.08 & 18 & 22 & 3 & 52 & 677,020 & 0.05 \\
\hline 11 & 0.09 & 18 & 14 & 3 & 63 & 642,190 & 0.05 \\
\hline 12 & 0.1 & 18 & 21 & 3 & 34 & 632,280 & 0.05 \\
\hline
\end{tabular}

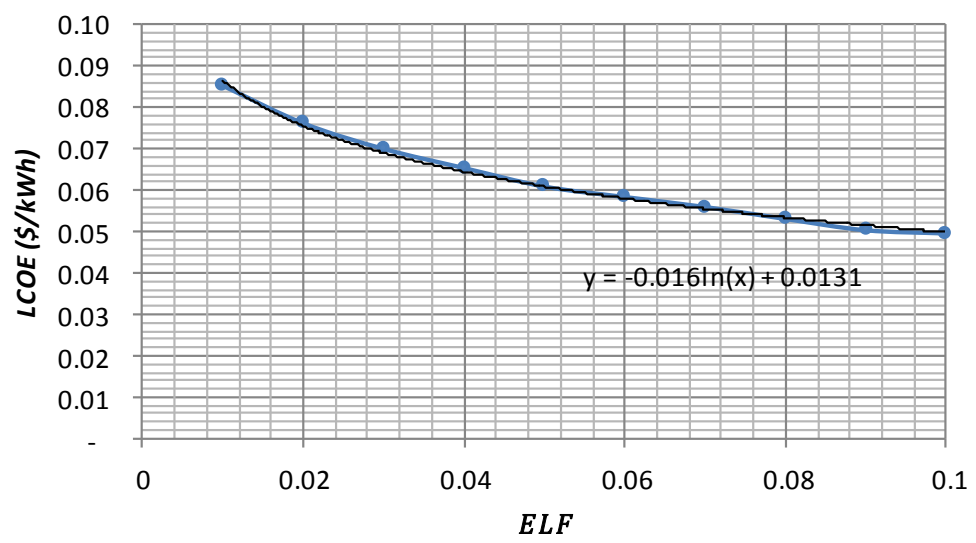


If some graph made from the simulation result will produce logaritmic equation $\mathrm{y}=$ $-0.016 \ln (\mathrm{x})+0.0131$ as shown in

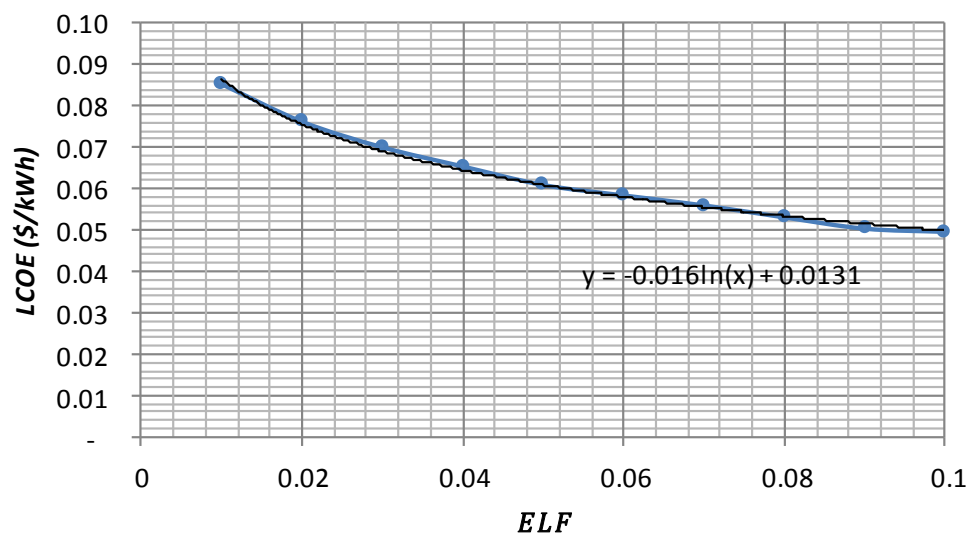

figure 9.

If the graphic made from the simulation result, will produce logaritmic equation $\mathrm{y}=$ $-0.016 \ln (\mathrm{x})+0.0131$ as shown

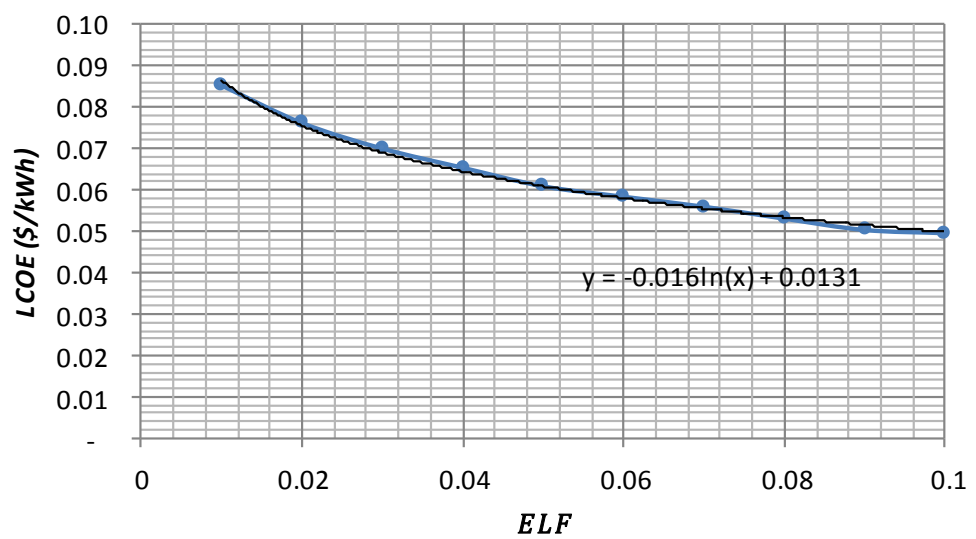

figure 9.

\section{Conclusion}

This research has proposed a hybrid renewable energy system to meet the $811.760 \mathrm{kWh}$ electricity need of $200 \mathrm{~kW}$ peak loads in rural areas for the 20 year project lifetime. The proposed hybrid system consists of a wind turbine, solar cells, micro-hydro generator as a generator component and battery, elektrolizer, hydrogen tanks and fuel cell as an energy storage system. The purpose of this study is to conduct optimization on the number of units generating HRPPbased on the hourly load and meteorology for one year data. Then,the simulation was made to optimize HRPP unit or component using the Particle Swarm Optimization (PSO) method. This simulation was made based on minimizing costs to meet the Equivalent Loss Factor (ELF) index.The ELF index limitation in this study was between 0.1 and 0.0001 .

From the simulation results, it can be seen that the cost is determined by the level of reliability that can be achieved; renewable energy sources and specifications and pricing tools that used. In addition, for the current time that the optimal configuration of HRPP is not 
included the fuel cell storage system. The configuration of generating units, NPC and LCOE for each ELF can be seen in table 10. From the table, it shows that the greater the ELF index, then the lower the costs. Conversely, the lower the ELF index (higher service quality) the higher costs. Figure 9 informs the function of equation chart among the LCOE in every ELF index.

\section{Reference}

[1]. A. Ahmed, Li Ran and J. Bumby, "Simulation and control of a hybrid PV-wind system," in Power Electronics, Machines and Drives, 2008. PEMD 2008. 4th IET Conference on, 2008.

[2]. Coppez, Gabrielle. Optimal Sizing of Hybrid Renewable Energy Systems for Rural Electrification. Masters of Science in Electrical Engineering. The University of Cape Town. 29 August 2011.

[3]. Javadi, M. R., R. Bazyar, A. Jalilvand, and M. Valizade. Technical and Economic Assessment of Stand-Alone Hybrid Renewable Energy System via PSO-TVAC Algorithm for Ardebil Area in North-West of Iran. The $9^{\text {th }}$ International Energy Conference. 2011

[4]. Navaeefard, S.M.M. Tafreshi, M. Barzegari and A.J. Shahrood. Optimal Sizing of Distributed Energy Resources in Microgrid Considering Wind Energy Uncertainty with Respect to Reliability. Energy Conference and Exhibition, pp. 820-825, 18-22, Dec. 2010.

[5]. M. Bashir and J. Sadeh. Size Optimization of New Hybrid Stand-alone Renewable Energy System Considering a Reliability Index. IEEE, 2012.

[6]. Hamid Hassanzadeh Fard, Seyed Masoud Moghaddas-Tafreshi, Seyed Mehdi Hakimi. Optimization of grid-connected microgrid consisting of PV/FC/UC with considered frequency control. Turkish Journal of Electrical Engineering \& Computer Sciences. 2013.

[7]. Kashefi Kaviani A, Riahy G.H, Kouhsari SH.M: 'Optimal design of a reliable hydrogenbased stand-alone wind/PV generating system, considering component outages'. Renewable Energy, 2009, 34, pp. 2380-2390.

[8]. Khan, M.J., M.T. Iqbal. Pre-Feasibility Study of Stand-Alone Hybrid Energy Systems for Applications in Newfoundland. www.elsevier.com. 2004.

[9]. Nowdeh, S. A., Ghahnavieh, A. A., and Khanabdal, S. PV/FC/Wind Hybrid System Optimal Sizing Using PSO Modified Algorithm. Buletinul Institutului Politehnic Din IASI, 2010.

[10]. R.S. Garcia, D. Weisser,. A wind-diesel system with hydrogen storage: joint optimization of design and dispatch, Renewable Energy, Vol. 31, pp. 2296-2320, 2006.

[11]. S.M. Hakimi, S.M. Moghaddas-Tafreshi. Optimal sizing of a stand-alone hybrid power system via particle swarm optimization for Kahnouj area in south-east of Iran, Elsevier Volume 34, Issue 7, July 2009, Pages 1855-1862.

[12]. Suryoatmojo, Heri. Artificial Intelligence Based Optimal Configuration of Hybrid Power Generation System, Dissertation Doctor of Philosophy in Department of Computer Science and Electrical Engineering, Graduate School of Science and Technology, Kumamoto University, Japan, 2010.

[13]. K. M. Iromi Udumbara Ranaweera, Techno-Economic Optimum Sizing of Hybrid Renewable Energy System -Rural Electrification In Srilanka-, Master Thesis, University of Agder, Grimstad, Norway, June 2013.

[14]. Masoud Ghazipour Shirvan, Ali Asghar Ghadimi. Determining the Capacity of Combined Distribution Generation Resources in an Independent Distributed Network Considering the Uncertainty Behavior of Load and Energy Resource. Indian Journal of Science and Technology, Vol 6(12), 5533-5541, December 2013

[15]. Fatemeh Jahanbani and Gholam H. Riahy, Optimum Design of a Hybrid Renewable Energy System, Electrical Engineering Department, Amirkabir University of Technology, Iran, www.intechopen.com, 2011 
[16]. J. Kennedy and R. C. Eberhart. Particle Swarm Optimization. In Proceedings of the 1995 IEEE International Conference on Neural Networks. IEEE Service Center, Piscataway, 1995.

[17]. Adhy Kurniawan, Pedoman Studi Kelayakan Hidrologi, Direktorat Jenderal Listrik dan Pemanfaatan Energi Departemen Energi dan Sumber Daya Mineral, 2009.

[18]. Andries P. Engelbrecht, Computational Intelligence: An Introduction, John Wiley and Sons, 2007.

[19]. Anggi Setyo Wibowo, Studi Perencanaan Pembangkit Listrik Tenaga Mikrohidro (PLTMH) Di Sungai Mirat Desa Taja Urap Kecamatan Tewah Kabupaten Gunung Mas Provinsi Kalimantan Tengah, Universitas Brawijaya, 2013.

[20]. http://hypertextbook.com/facts/2005/MichelleFung.shtml.

[21]. http://www.hydrogen.energy.gov/pdfs/review12/st100_james_2012_o.pdf.

[22]. Burton, T., Sharpe, D., Jenkins, N., Bossanyi, R. Wind Energy Handbook. England. John Wiley \& Sons, LTD. 2001.

[23]. Chris Rayment, Scott Sherwin., Introduction to Fuel cell Technology, Department of Aerospace and Mechanical Engineering, University of Notre Dame, Notre Dame, IN 46556, U.S.A. May 2, 2003.

[24]. EG \& G Technical Services Inc., The Hydrogen Fuel cell Power System, West Virginia, 2004

[25]. Fuel cell Handbook, U.S. Department of Energy, Office of Fossil Energy, National Energy Technology Laboratory, November 2004.

[26]. Fuel cell Technologies Program, EERE Information Center, February 2011.

[27]. Henryson, M., Svensson, M. Renewable Power for the Swedish Antarctic Station Wasa. SWEDARP, Swedish Polar Research. Department of Energy Technology Stockholm, Sweden. 2004.

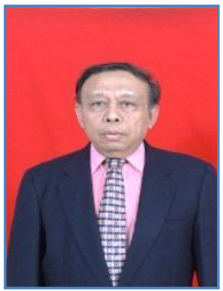

Yusra Sabri received his Sarjana (Bachelor) degree in Electrical Engineering from Institut Teknologi Bandung (ITB), Indonesia 1976 and his Dipl.Ing, DEA and DR.Ing degrees in Electrical Power Engineering from Institut National Polytechnique de Toulouse, France in 1977,1978 and 1981 respectively. He is currently working as lecturer in The School of Electrical Engineering and Informatics ITB. His research interests are in Power and Distribution System Planning.

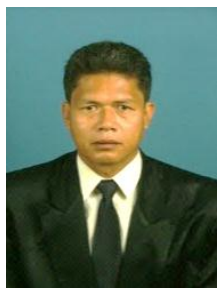

Hermaga Santos Zein received his Sarjana (Bachelor) degree in Electrical Engineering from Institut Teknologi Bandung (ITB), Indonesia 1986 and received his M.Sc and DR. degree in Electrical Power Engineering from Institut Teknologi Bandung (ITB) in 1991 and 2005 respectively. He is currently working as lecturer in Politeknik Negeri Bandung. His research interests are in Energy and Power System Planning. 


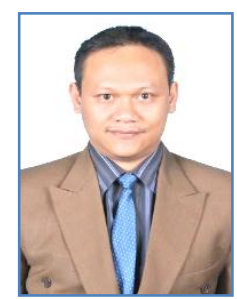

Erwin Yusuf received his Sarjana (Bachelor) degree in Electronic \& Instrumentation Engineering from University of Padjadjaran (UNPAD), Indonesia 2005 and received his M.Sc degree in Electrical Power Engineering from Institut Teknologi Bandung (ITB) in 2014. He is currently working as lecturer in Politeknik Negeri Bandung. His research interests are in Energy and Power System Planning. 